\title{
ISSUES ON THE ENFORCEMENT OF INTERNATIONAL HUMANITARIAN LAW TO THE USE OF DRONES IN ARMED CONFLICTS
}

\author{
Sabin GUȚAN \\ “Nicolae Bălcescu” Land Forces Academy, Sibiu, Romania \\ sabin_gutan@yahoo.com
}

\begin{abstract}
Drones are new means and methods of warfare which, apparently, are similar to combat aircrafts. A big difference between the two categories is the human personnel involved. Compared with airplanes, carrying a human crew on board - this one carrying out combat operations from inside the aircraft - drones do not have inside human beings, being coordinated from the ground (or sea) - the military actions carrying out from the place where the operators are. So the question arises: what kind of rules of international humanitarian law are applicable to the use of drones in armed conflicts? Starting from the rule that legal rules apply to legal relationships between people (but not directly to objects or animals), I analyze to what extent these means and methods of warfare are subject to the rules of armed conflict on land, sea or air.
\end{abstract}

\section{Keywords: land warfare, air warfare, drones, international humanitarian law}

\section{Introduction}

Drones are remote controlled aerial equipments used in both civilian and military fields. They are also known under the names: Unmanned Aerial Vehicle (UAV) or Unmanned Combat Aerial Vehicle (UCAV). However, they do not act on their own, but are coordinated remotely from human operators. That's why, in the UK, they are called Remotely Piloted Aircraft. [1]

International humanitarian law does not provide information and technical methods to use weapons, but only the legal limits of their use to minimize the destructive effects of the war. International humanitarian law provides such data only for prohibited weapons and ammunitions. The fact that drones are not explicitly mentioned by international humanitarian law does not mean that they are not regulated but, on the contrary, they are legal, as they only attack legal targets by legal means - and in terms of the use of the drones, this is practically possible. They must first comply with the provisions of Article 36 about New Weapons in the 1977 Additional Protocol I. The failure of the drones to honour a number of protection rules (to take prisoners of war, to provide care to wounded and sick, etc.) is not the subject of this study.

The question that is being discussed in this paper is what set of rules applies to the drones? A tank is subject to the rules of land warfare (acting on the ground), a ship or submarine of war is subject to the rules of the naval warfare (acting on water), a combat aircraft is subject to the rules of air warfare (acting in the air).

\section{The legal nature of the combat drones From the way the rules of international humanitarian law are regulated, three fundamental rules can be observed: \\ A. Applying rules of conduct depends on where the fighter operates; \\ B. Application of the protection rules is related to the place where the protected persons are located;}


C. When the first two rules interfere, the second has priority - (e.g. air or sea attack to the ground - Article 49/3, Article 57/4 Additional Protocol I 1977). From the perspective we are speaking of, we do not deny the legality of using military drones in armed conflicts. This problem is no more or less questionable than the use of other weapon systems considered legal (artillery, tanks, missiles, ships and military submarines, military aircraft). The only aspect that makes them special is novelty. The same happened in 1899 when states agreed ,to prohibit, for a term of five years, the launching of projectiles and explosives from balloons, or by other new methods of similar nature" [2] (provision reiterated by the Second Convention of The Hague of 1907). But today, there is no problem anymore, bombing of any kind being an indispensable method in armed conflicts. It is only now that they are done through the drones. Similarly, the work of a sniper can be made easier by a drones. This debate would no longer matter when we analyse the legality of launching a nuclear bomb from a military plane or a military drones. The basis for the lawfulness of the use of a weapon or weapon system is the ability to respect the fundamental principles of international humanitarian law - distinction, proportionality, discrimination in attack, limitation, and humanity - and drones fall within this context. Problems arise from the human factor that uses drones - and this may be fairness, error or bad faith.

The manual of international law applicable to air warfare and missiles considers drones as planes - ,any vehicle whether manned or unmanned". [3] Taking into account the fact that in the air warfare the execution of an attack with a combat aircraft is considered as a means of combat, also the use of drones must be considered, in accordance with international humanitarian law, as a means of combat. [4]

\section{Drones - means of land or aerial warfare?}

The rules of international humanitarian law do not apply uniformly, but depending on the types of operations and forces involved: land, sea and air. In order to determine which rules apply to new combat means and methods, it is first necessary to establish the category to which they belong. The rules of land warfare apply to forces acting on the ground (irrespective of the type of means and methods of combat used), the rules of the maritime warfare apply to forces operating at sea and the rules of the air warfare apply to forces acting in the air. And these rules refer to the actual presence of the combatant in the battlefield.

Similar to the use of drones is the use of missiles, which can also be routed from the ground, sea or air. In international humanitarian law, missiles are not considered as specific means and methods of air warfare, although they fly through the air to the target. They shall be subject to the rules specific to where they are leaving or where they strike. [5] Moreover, air attacks on land targets are governed by the rules of the land warfare, and the actions of airplanes above the sea or aircraft attacks on the naval forces are governed by the rules of the naval warfare. [6]

In the United Kingdom, unmanned airplanes are subject to the same domestic and international legal rules as apply to airplanes with human crew. [7] Moreover, the use of the drones is given to the competence of the air forces. The same situation is found in the US Air Force, which uses drones and prepares staff (,pilots”) for their handling. [8]

Two fundamental principles of law helps us identify the correct legal status of using drones: legality and legal responsibility. It follows from both principles that no one is above the law, and every individual (physical or legal - including states, authorities, and international organizations) is responsible for his own deeds or for acts committed by persons or goods under his 
responsibility. These principles are wellestablished in international humanitarian law and criminal international law - from obligations and accountability of states to individual obligations and accountability. In this context, the use of drones must first be subject to these principles, and the responsibility always lies with the persons authorized to use them.

In the international armed conflict, only combatants have the right to commit acts of hostility against the enemy. The use of military drones is an act of hostility, and this use must be subject to the rules of the combatant's status. Thus, all persons who coordinate drones attacks must be combatants within the meaning of Articles 1-3 of the Regulations Annex to the Fourth Hague Convention of 1907 and Articles 43 and 44 of the Additional Protocol I of 1977. Other people using drones in military operations are illegal combatants - for example, CIA agents. [9]

In internal armed conflicts, neither the status of combatant nor the status of prisoner of war is recognized. In internal armed conflicts, it is forbidden to attack civilians who are not directly participate in hostilities, but do not restrict their participation in hostilities. These issues remain under the domestic law of each state. [10]

A drone in itself cannot take responsibility for its actions, no matter what level of autonomy it has. Also, the combatant can only be considered a human being, and technology can only be considered as means and methods of warfare. If the pilots and crews of the military airplanes in action are subject to the rules of air warfare, being in the air - with the exception of land attacks (the rules of the land warfare) and attacks at sea (the rules of the naval warfare), military drone in action does not carry human crew. Operators must be subject to the rules of law of the place where they are located - on the land, at sea or in the air. It can therefore easily be said that military drones are not means and methods of the air warfare, which is also the case for missiles. As a matter of fact, the place where the drone operators are becomes a theatre of war and all the goods (mobile and immovable) used by them for combat purposes become military objectives. All of these must be subject to the roles of the land warfare, even if the drones fly.

\section{Conclusions}

Beyond the question of the legality of using of the new weapons, as is the case with the drones, there is the issue of the set of rules applicable to these weapons. As is well known, each type of warfare - land, sea and air - has a special set of applicable rules, in addition to the common body of rules of international humanitarian law. The present shows, however, that there can be no pure land or pure maritime or pure air warfare, but modern wars are mixed, using all kinds of forces, combined actions and different types of battlefields. More and more means and methods of warfare acquire specific features of both air and sea and land conflicts. There are weapons that can leave the ground, fly through the air and hit targets on the sea; or weapons that leave the sea or under the sea, fly through the air and hit ground targets - especially missiles and, more recently, drones. Moreover, even if some weapons fly and attack from the air, they are coordinated from the ground or at the sea by humans. In this context, the strict application of international humanitarian law rules is getting harder and, indeed, the need for reformulation is felt.

That is why in the modern war there is no justification for the existence of separate rules for each type of battlefields and for each type of armed forces (land, naval and air), these rules having to merge into a unitary set of regulations. Thus, the evercontroversy will not arise: what rules do we apply to a military operation or to the use of certain means and methods of warfare?; Are they regulated or not?; Are they forbidden or not?; Is it an armed conflict on land, sea or air?; Is the air warfare regulated or not?, 
and so on...

Considering the principle of legality, the method of legal analogy and the principle of legal responsibility, we can only apply the rules applicable to the direct user of these means and methods of warfare for both missiles and drones. If the operator is on the land, even if the drones fly and attack to the air, the rules to be observed must be primarily those of the land warfare.

Why do we need special rules for maritime warfare (as enshrined in the 1994 San Remo Manual on International Law applicable to Conflict at Sea) or special rules for air warfare and for the use of missiles (as enshrined in The HPCR Manual on International Law Applicable to Air and Missile Warfare, 2009). We appreciate that this differentiated regulation, specific to the 19 th and 20th centuries, is no longer up to date. It is imperative that international law be reformed in its entirety, in particular by eliminating the separation between land, sea and air warfare, but also between the international armed conflict and the internal armed conflict.

\section{References}

[1] Titus Hattan, Lethal Autonomous Robots: Are They Legal under International Human Rights and Humanitarian Law?, NEBRASKA LAW REVIEW, vol.93, pp. 1035-1057, 2014, p.1035

[2] Declaration (IV,1), to Prohibit, for the Term of Five Years, the Launching of Projectiles and Explosives from Balloons, and Other Methods of Similar Nature. The Hague, 29 July 1899

[3] Section A: 1) d) of HPCR Manual on International Law Applicable to Air and Missile Warfare, 2009, p.1

[4] Petra Ochmannová , Unmanned Aerial Vehicles and Law of Armed Conflict Implications, Czech Yearbook of Public \& Private International Law (Vol.2), pp. 143-157, 2011, p.148

[5] Frauke Lachenmann, Rüdiger Wolfrum, The Law of Armed Conflict and the Use of Force. The Max Planck Encyclopedia of Public International Law, Oxford University Press, 2016, p.745

[6] Marco Sassoli, Antoine A. Bouvier, Anne Quintin, How Does Law Protect in War?, ICRC, Third Edition, 2011, Volume I, Chapter 11, p.2

[7] Louisa Brooke-Holland, Overview of military drones used by the UK armed forces, The House of Commons Library, Briefing Paper Number 06493, pp. 1-53, 8 October 2015, p.33

[8] Oren Gross, The New Way of War: Is There a Duty to Use Drones?, FLORIDA LAW REVIEW, Vol. 67, pp. 1-72, 2015, p.8

[9] Melina Sterio, The United States' Use of Drones in the War on Terror, Case Western Reserve Journal of International Law, Vol. 45, pp.197-214, 2012, pp.212-213

[10] Michael N. Schmitt, Unmanned Combat Aircraft Systems and International Umanitarian Law: Simplifying the Oft Benighted Debate, Boston University International Law Journal, Vol. 30, pp.595-619, 2012, p.618 